PF 2020 (75/1): 215-240

https://doi.org/10.32798/pf.658

\author{
VÁCLAVA KETTNEROVÁ \\ Matematicko-fyzikální fakulta \\ Univerzita Karlova \\ Ústav formální a aplikované lingvistiky, Praha \\ e-mail: kettnerova@ufal.mff.cuni.cz
}

ORCID 0000-0001-9694-1304

\title{
DERIVED LEXICAL RECIPROCAL VERBS IN CZECH ${ }^{1}$
}

\begin{abstract}
In Czech (as in other Slavic languages), clitic reflexives serve - among others - as a derivational means of deriving lexical reciprocal verbs, i.e., the verbs that encode mutuality directly in their lexical meaning. Here I draw a line between those lexical reciprocal verbs with which the reflexives introduce mutuality (nenávidèt se 'to hate each other' $\longleftarrow$ nenávidèt 'to hate sb' and slibit si 'to promise sth to each other' $\leftarrow$ slibit 'to promise sth to sb') and those with which the reflexives have another function (oddělit se 'to separate from each other' $\leftarrow$ oddèlit 'to separate sb/sth from sb/sth'). It will be shown that lexical reciprocal verbs of the former type form without exception the so-called discontinuous constructions with the nominative subject and the commitative indirect object (Petr si slibil s Marií věrnost. 'Peter and Mary promised fidelity to each other.'), and that they fall into several semantic classes, which, however, semantically overlap to a great extent with lexical reciprocal verbs of other types.
\end{abstract}

KEYWORDS: reciprocity, valency, derivation, clitic reflexives

SŁOWA KLUCZOWE: wzajemność, walencja, derywacja, klityki refleksywne

\section{Introduction}

Reciprocity comprises language means encoding mutuality. Despite being a rather infrequent language phenomenon (Evans et al. 2011), it attracts considerable attention in current linguistics (König, Gast 2008; Nedjalkov 2007; Evans

1 The research reported in this paper has been supported by the GA ČR grant No. 18-03984S, "Between Reciprocity and Reflexivity: The Case of Czech Reciprocal Constructions" and partially by the grant LINDAT/CLARIAH-CZ No. LM2018101; this work has been using language resources distributed by the latter grant. 
et al. 2011). In particular, the cross-linguistic variance in language means encoding mutuality and the extent to which they are grammaticalized are intensively studied (Maslova, Nedjalkov 2013). Evans (2008, p. 92) states that crucial tasks in further research into reciprocity lie esp. in detecting, among others, the following correlations: the correlation between semantic types of reciprocals and syntactic constructions which they form, and the correlation between syntactic constructions and their effect on valency. In this paper, I tackle these two tasks, focusing on reciprocal verbs in Czech the lemmas of which are marked by the reflexive se or si. On the basis of their syntactic and semantic properties, I address their position within other reciprocal verbs bearing the trait of mutuality. The inventory of verbs discussed here is drawn from the Czech National Corpus ${ }^{2}$ (Křen et al. 2019) and from the VALLEX lexicon ${ }^{3}$ (Lopatková et al. 2016).

\section{Mutuality and its encoding in Czech}

\subsection{Mutuality}

Under the term mutual predicate I understand such a predicate that denotes a situation in which it holds for some of its participants $A$ and $B$ that the relation of the participant $\mathrm{A}$ to the participant $\mathrm{B}$ is the same as the relation of the participant $\mathrm{B}$ to the participant A (see, e.g., Knjazev 2007a; Haspelmath 2007; Evans 2008; similarly Frajzyngier 2000) ${ }^{4}$. Mutual predicates can be represented by a verb (1), noun (2), adjective (3) or an adverb (4). Within mutual predicates, only verbs are discussed hereinafter.

(1) Děti si (spolu) házeli s míčem.

'Children were throwing a ball to each other.'

(2) Petrova a Pavlova di̊věra $k$ sobě navzájem

'Peter and Paul's confidence in each other'

(3) Členové rodiny jsou $k$ sobě laskaví.

'Family members are kind to each other.'

(4) rovnoběžně $k$ sobě

'parallelly to each other'

\footnotetext{
2 https://www.korpus.cz/

3 http://ufal.mff.cuni.cz/vallex/3.5/

4 There are also predicates with which more than two participants can be involved in mutuality. However, in Czech these predicates occur only very rarely (e.g., préedstavit 'to introduce' and seznámit 'to introduce'). Due to their sparseness and the fact that Czech has no special marking for these predicates, I leave them aside here.
} 
Mutuality can be formally defined in a way introduced by König and Gast (2008): "A binary predicate $R$ is reciprocal on a set A iff: $x, y \in A[x \neq y \rightarrow R(x, y)]$ and $|A| \geq 2$ " (König, Gast 2008, p. 7). ${ }^{5}$ As it follows from this definition, mutual predicates form constructions involving at least two propositions (e.g., Petr a Marie se líbají. 'Peter and Mary kiss each other.' encompasses the propositions Petr líbá Marii. 'Peter kisses Mary.' and Marie líbá Jana. 'Mary kisses John.') (see, e.g., Evans 2007; Evans 2008; Haspelmath 2007; Nedjalkov 2007). Such complex events expressed in a single clause inevitably lead to the neutralization of some semantic distinctions (see esp. Maslova 2008, p. 243). First, what typically is not linguistically encoded are different configurations of the mutual relation between semantic participants with multiple referents (e.g., Děti se koulují. 'The children are snowballing.' can refer, among others, to the situation when two children are mutually snowballing each other (called, e.g., by Evans et al. 2011, strong reciprocal), or when more than two children are snowballing in pairs (pairwise reciprocal), as well as when a group of children have a snowball fight against one child (radial reciprocal), or when a group of children are chaotically snowballing each other (melee reciprocal). Although the different configurations of semantic participants in the mutual relation are described in detail by formal semanticists with respect to different truth-conditions (see e.g. Langendoen 1978; Dalrymple et al. 1998; Evans et al. 2011), they have no specific linguistic marking in Czech, see esp. remarks on vagueness of reciprocal constructions in Czech by Panevová (2007).

Second, the propositions involved in reciprocal constructions indicate events that can happen either at the same time as a single event or at different times as a series of asymmetric events (Kemmer 1993, p. 109; Evans 2008; Siloni 2008). Some mutual predicates allow only for a simultaneous interpretation of the corresponding events (e.g., Petr a Karel se včera potkali. 'Peter and Charles met each other yesterday.'), other mutual predicates, being segmented into separate sub-events, have rather the sequential reading (e.g., Manželé si dávali drahé dárky. 'The husband and wife gave expensive gifts to each other.'), and still others can have both readings, which in many cases remain indistinguishable even in larger contexts (e.g., Bratři se pozdravili. 'Brothers were greeting each other.' may be interpreted simultaneously, if they hugged each other, or sequentially, if they said hello to each other). In Czech, the semantic distinction between simultaneous and sequential interpretation of events is not linguistically marked (cf. also Maslova 2008; Plank 2008). Despite that, I take this semantic distinction into account (see Section 4.1.10) as it is considered in some works as one

\footnotetext{
See also similar definitions of the so-called strong reciprocity in (Langendoen 1978; Dalrymple et al. 1998) and the so-called symmetric predicates in (König, Kokutani 2006).
} 
of the determining factors in delimiting the reciprocal verbs the lemmas of which are marked by the reflexives contributing the trait of mutuality (see esp. Kemmer 1993; Dimitriadis 2008; Siloni 2008).

\subsection{Reciprocity}

While mutuality is considered as belonging to a semantic plane, reciprocity refers to an inventory of language means encoding this semantic relation, see esp. Haspelmath (2007). In Czech, mutuality is lexically and/or grammatically encoded. First, mutuality is encoded directly in the lexical meaning of some verbs. I refer to verbs with the semantic trait of mutuality in their lexical meaning as lexical reciprocals. Second, mutuality is expressed by grammatical means involved in the syntactic operation of reciprocalization. This operation, resulting in constructions here referred to as reciprocal constructions, can be applied to verbs that do not express mutuality but allow some of their participants to enter into this relation. These verbs are called here syntactic reciprocals since applying the syntactic operation of reciprocalization is the only way of expressing mutuality with them. Moreover, lexical reciprocals can be subject to syntactic reciprocalization as well. With both syntactic and lexical reciprocals, this operation allows some of their semantic participants to be put into a perfect symmetry (for unequal involvement of participants in events with lexical reciprocals see Section 3.1). ${ }^{6}$

As in other Slavic languages (Wiemer 2007; Ivanová 2020; Knjazev 2007b; Penchev 2007; Siloni 2008), reflexives in Czech serve as the primary marker of mutuality within both lexical and syntactic reciprocals, for Czech see (Panevová 1999; Panevová 2007; Panevová, Mikulová 2007; Kettnerová, Lopatková 2018; Kettnerová, Lopatková 2019). The reflexives function as part of reciprocal verb lemmas (the clitic reflexives $s e$ and $s i$ ) or as the pronoun (the clitic se or si and the long forms sebe, sobé, and sebou), filling one of their valency positions. Here I follow the traditional view in which those clitic reflexives se and $s i$ that can be substituted by the long forms sebe and sober, respectively, if, e.g., topicalized, are considered to be positional variants of the reflexive pronoun (e.g., Dưvéřovali si. 'They trusted each other.' and Sobě dưvěrovali, ostatnim ne. 'They trusted each other but they did not trust others.'). The analysis of the clitic reflexives replaceable by the long forms as the reflexive pronoun makes it possible to assign the identical status in the language description to the

\footnotetext{
6 A similar distinction between mutual predicates is drawn by Nedjalkov (2007) (lexical and grammatical (derived) reciprocals), by Siloni (2008) (lexical and syntactic reciprocals), and by Dimitriadis (2008) (the so-called symmetric and non-symmetric predicates), in Czech by Panevová and Mikulová (2007) (inherent reciprocal verbs and lexically non-reciprocal verbs).
} 
functionally equivalent reflexives (Kettnerová, Lopatková 2020).7 Alternatively, the unambiguous bipartite expression jeden - druhy' 'each other', filling one of valency positions of reciprocal verbs, can be used instead of the reflexive pronoun.

Let me exemplify reciprocal constructions of the syntactic reciprocals fotografovat 'to take photos', hrozit 'to threaten', and soucitit 'to sympathize', and of the lexical reciprocals diskutovat 'to discuss', oddèlit 'to separate', and komunikovat 'to communicate', resulting from the operation of syntactic reciprocalization. As a result of this operation, the semantic participants involved in mutuality are usually expressed in two surface positions at the same time, e.g., in example (5), the persons who are taking photos and the ones who are photographed are expressed in both the nominative subject and accusative direct object.

As to changes in the involved syntactic positions, a syntactically more prominent surface position (subject (5)-(7) and (10) or direct object (8)) is filled with a noun in the morphological plural (5) and (8), with nouns in the coordinated group (6) and (10) or with a collective noun (7). A less prominent surface position is occupied by the reflexive pronoun (5) and (8)-(9) or by the bipartite expression jeden - druhy' 'each other' (6) and (10); the morphemic forms of the bipartite expression jeden - druhy' 'each other' are discussed by Kettnerová and Lopatková (2020). However, if the less prominent position has the comitative form ( $s+$ instrumental in Czech), the reflexive pronoun is predominantly excluded, and the position is deleted from the surface (7). Only sporadically, the reflexive pronoun in the comitative form is present (9). Alternatively, the position in the comitative form can be occupied by jeden - druhy' 'each other' (10). Both the reflexive pronoun and the expression jeden - druhy' 'each other' corefer with the expression in the more prominent position of subject (5)-(6) and (10) or direct object (8). ${ }^{8,9}$

7 In Czech linguistics, there is a controversy about the pronominal status of the clitic reflexives. Some scholars take changes in agreement of secondary predicates as evidence against the pronominal status of the clitic reflexives (cf., the secondary predicate Büh 'God', changing agreement depending on the form of the reflexive in Petr ${ }_{\text {nom }}$ vnímá sebe $e_{\text {acc }}$ jako Boha $a_{\text {acc }}$. and Petr ${ }_{\text {nom }}$ se vnímá jako $B u ̛ h$ nom. 'He sees himself as God.), see esp. (Karlík 1999; Oliva 2001; Medová 2009; Veselý 2018). However, Fried (2004) argues that the morphemic change in agreement is not reason enough to completely reject the pronominal status of the clitic reflexives; see Svoboda (2014) as well.

Adverbials spolu, vzájemně, navzájem, and mezi sebou 'mutually' are only rarely a primary marker of mutuality in Czech. These adverbials usually stress the meaning of mutuality or disambiguate between mutuality and reflexivity (see, e.g., the sentence Rodiče se vzájemně obviňovali. 'Parents accused each other.' which - without the adverbial vzájemně 'mutually' - has either reciprocal or reflexive meaning). Only in cases where there is no overt marker of mutuality (esp. where the comitative is deleted from the surface), one of the listed adverbials takes over the role of the primary marker of mutuality (e.g., Lidé spolu soucítili. 'People sympathize with each other.), see (Kettnerová, Lopatková 2020).

9 The application of the rules of the syntactic reciprocalization to a lexical reciprocal derived from a syntactic reciprocal (e.g., nenávidèt se 'to hate each other') (Section 3.2.1 and 3.3.1) and the respective syntactic reciprocal (e.g., nenávidèt 'to hate') typically results in the same surface structure which should be thus interpreted as ambiguous (e.g., Petr a Jan se nenáviděli 'Peter and John hated each other' can be 
(5) Kamarád-i $\underline{s e}$

fotografuj-í.

friend-NOM.PL.M

REFL.ACC

photograph-3.PL

'The friends are taking photos of each other.'

(6) Petr- $\varnothing$ a Jan- $\varnothing$

hroz-í udáním

Peter-NOM.SG.M and John-NOM.SG.M

threaten-3.PL

with denuncia-

jeden- $\emptyset$

druh-ému.

one-NOM.SG.M

second-DAT.SG.M

'Peter and John threaten each other with denunciation.'

(7) $\underline{\text { Rodin- } a}$

o problém-u

family-NOM.SG.F

about problem-LOC.SG.M

diskutuj-e.

'The family discusses about the problem.'

(8) Rozhod ̌̌-í

referee-NOM.SG.M

od sebe

oba rváč-e oddělil-Ø. (SYN2010)

from REFL.GEN

both fighter-ACC.PL.M separated-3. SG.M

'The referee separated both fighters from each other.'

(9)

...hlavně komunikuj-í

se sebou

navzájem.

... mainly communicate-3.PL

with REFL.INSTR mutually

'They mainly communicate with each other'

(10) Petr- $\varnothing$ a Jan- $\varnothing$

Peter-NOM.SG.M and John-NOM.SG.M

soucít-í

jeden- $\varnothing$

sdruh-ým.

sympathize-3.PL

one-NOM.SG.M

with second-INSTR.SG.M

'Peter and John sympathize with each other.'

\section{Lexical reciprocals in Czech}

\subsection{General characteristics}

As the trait of mutuality is encompassed in the lexical meaning of lexical reciprocals (Section 2.2), they can potentially express mutuality between some of their participants without applying the syntactic operation of reciprocalization, that is even in their base constructions, in which these participants are mapped onto separate syntactic positions ${ }^{10}$. In this case, a strong implicature of the relation of mutuality

interpreted as derived from the non-reflexive syntactic reciprocal nenávidèt 'to hate' or as derived from the reflexive lexical reciprocal nenávidét se 'to hate each other'). Different types of ambiguity of reciprocal constructions in Czech are thoroughly discussed by Kettnerová and Lopatková (2020).

10 See the so-called discontinuous constructions in (Dimitriadis 2008) and for Polish (Wiemer 2007). 
is conditioned by semantic and pragmatic homogeneity of semantic participants and by their equal involvement in the denoted events, see esp. (König, Kokutani 2006) and for Czech (Panevová 1999; Panevová 2007). If homogeneous participants are equally involved in the expressed event, they are typically invertible in the affected syntactic positions. For example, if sentence (11) expresses the situation when Peter and John fight with each other, then their inversion in the involved syntactic positions is possible (11'), see examples (12) and (12') as well ${ }^{11}$. In the case of non-homogeneous participants and/or their unequal participation in the expressed event, their inversion in the affected syntactic positions is usually impossible (11"), (13)-(13') and (16) or it can lead to a semantic shift (14)-(14') and (15)-(15'). A full mutuality between semantic participants as defined in Section 2.1 is achieved in reciprocal constructions, resulting from the operation of syntactic reciprocalization (Section 2.2) applied to lexical reciprocals, see example (14").

(11) Petr bojuje s Janem.

'Peter fights with John.'

(11') Jan bojuje s Petrem.

'John fights with Peter.'

(11") Jan bojuje s větrnými mlýny.

'John fights with windmills.'

(12) Kravata ladí s košilí.

'The tie matches the shirt.'

(12') Košile ladí s kravatou.

'The shirt matches the tie.'

(13) ... kdy se s městem sloučila obec Holice ... (SYN2009pub)

'... when the village of Holice united with the town ...'

(13') ... ?? kdy se mèsto sloučilo s obcí Holice ...

'...? ?hen the town united with the village of Holice ...'

(14) Petr se rozvádís Marí.

'Peter is divorcing with Mary'.

(14') Marie se rozvádís Petrem.

'Mary is divorcing with Peter.'

(14") Petr a Marie se rozvádèjí.

'Peter and Mary are divorcing.'

(15) V tréninkovém centru si rozvernè vypráví se spoluhráči ... (SYN2013pub)

'He cheerfully talks with his teammates in the training center ...'

11 The inversion of semantic participants in their syntactic positions is used as an informal test identifying lexical reciprocals, see esp. (Nedjalkov 2007; Evans 2008; Haspelmath 2007). 
(15’) V tréninkovém centru si s ním spoluhráči rozverně vyprávějí...

'His teammates cheerfully talks with him in the training center ...'

(16) Čína soupeří s Japonskem, ale Japonsko s Čínou souperit nehodlá.

'China competes with Japan but Japan does not intend to compete with China.'

\subsection{Derivational aspects of reflexive lexical reciprocals}

Lexical reciprocals in Czech can have their verb lemmas unmarked (e.g., mluvit s někým 'to talk with sb'; vyjednávat s někým 'to negotiate with sb'; zápasit s někým 'to wrestle with sb') or marked by the reflexive se or $s i$; the latter are called here reflexive lexical reciprocals ${ }^{12}$. If a non-reflexive counterpart can be detected for a reflexive lexical reciprocal, a function of the reflexive can be specified on the basis of semantic and/or syntactic differences between the reflexive lexical reciprocal and its non-reflexive counterpart. From the point of view of reciprocity, a basic line can be drawn between those reflexive lexical reciprocals to which the reflexives contribute the trait of mutuality (Section 3.2.1) and those which they supply with another semantic trait (Section 3.2.2). If no non-reflexive counterpart can be found for a reflexive lexical reciprocal, no overt function of the reflexive can be determined from a synchronic perspective (Section 3.2.3). ${ }^{13}$

The treatment of the reflexive in these cases as a derivational means of deriving separate verb lemmas representing individual lexical units is, however, questioned by e.g. Haspelmath (2007). However, when a reflexive verb and its respective non-reflexive counterpart are compared, the situational meaning of the reflexive verb (a number and/or a type of participants of the situation denoted by the verb) as well as its structural meaning (a number and/or a type of valency complementations) are typically changed; for the only exception see Section 3.2.2.3. Either of these changes serves as an argument for considering the reflexive verbs as separate lexical units, see Kováčová (2005) and Kettnerová (2014). The former type of changes can be illustrated, e.g., (i) by autocausatives, where the acting and affected participant are conflated into an indistinguishable single participant (and thus the number of participants is reduced, see Section 3.2.2.2) and (ii) by lexical reciprocals derived from syntactic reciprocals where it is the type of participants that is subject to changes reflecting their equal participation in the denoted event (Section 3.2.1). The changes in the situational meaning under (i) bring about a reduction of one valency complementation, the latter changes under (ii) lead to changes in morphosyntactic expression of the affected participants (Section 3.3.1).

12 See Siloni (2008) as well.

13 For Czech see also Štícha et al. (2013, p. 429), for Slovak Ivanová (2020). 


\subsubsection{Derivation from syntactic reciprocals}

In Czech, there is a restricted group of reflexive lexical reciprocals that semantically differ from their base verbs just in the trait of mutuality ${ }^{14}$. These reflexive lexical reciprocals thus acquire the semantic trait of mutuality in the derivational process and this semantic feature is provided by the reflexive. Although the base verbs of these reflexive lexical reciprocals do not bear the feature of mutuality in their lexical meaning, they uniformly allow some of their participants to enter into mutuality, falling thus within syntactic reciprocals (Section 2.2). In base unreciprocal constructions of these syntactic reciprocals, one semantic participant that can be involved in mutuality is mapped onto the subject in nominative and the other is mapped either onto the direct object in the non-prepositional accusative or onto the indirect object in the non-prepositional dative. The distribution of the reflexive se and $s i$ with reflexive lexical reciprocals derived from syntactic reciprocals depends then on the morphemic form of the semantic participant expressed in the less prominent position with their respective base syntactic reciprocals. If this participant has the accusative form, the reflexive se is applied (e.g., fackovat se s nékým 'to slap each other's face' $\leftarrow$ fackovat někoho acc 'to slap sb’s face'; nenávidèt se s někým 'to hate each other' $\leftarrow$ nenávidět někoho acc 'to hate sb'; vitat se s někým 'to greet with each other' $\leftarrow$ vitat někoho acc 'to greet sb'). If this participant has the dative form, si is attached to the verb lemma (e.g., nadávat si s někým 'to curse each other' $\leftarrow$ nadávat někomu $u_{\mathrm{dat}}$ 'to tell sb off'; povídat si s někým 'to talk with each other' $\leftarrow$ povídat někomu $u_{\text {dat }}$ néco 'to tell sb sth'; vypomáhat si s někým 'to assist each other' $\leftarrow$ vypomáhat někomu ${ }_{\mathrm{dat}}$ 'to assist').

Reflexive lexical reciprocals derived from syntactic reciprocals (henceforth LRSs) are typically characterized by the same number of semantic participants as their non-reflexive counterparts but their types are reinterpreted so that they reflect equal participation of the respective participants in the event (e.g., the syntactic reciprocal povídat někomu něco 'to tell sb sth' is characterized by Speaker, Recipient, and Message while the lexical reciprocal derived form this verb povídat si s někým 'to talk with each other' is endowed by Interlocutor_1, Interlocutor_2, and Topic; the first two semantic roles reflect the same participation of the respective participants in the event). The valency behavior of LRSs is described in Section 3.3.1 and their semantic properties are introduced in Section 4.1.

\subsubsection{Derivation from lexical reciprocals}

Reflexive lexical reciprocals can be derived from non-reflexive lexical reciprocals (henceforth LRLs) as well. In this case, only the reflexive se is attested as

14 In rare cases, this trait implies an additional semantic shift as demonstrated in Section 3.3.1. 
the derivational means ${ }^{15}$. With these verbs, the reflexive $s e$ has a different role than conveying mutuality (as the trait of mutuality is already present in the nonreflexive base verbs). LRLs rank among decausatives (Section 3.2.2.1), autocausatives (Section 3.2.2.2) and deaccusatives (Section 3.2.2.3), see esp. (Geniušiené 1987), and for Polish (Wiemer 2007).

\subsubsection{Decausatives}

Decausatives ${ }^{16}$ differ semantically from their base verbs (typically verbs denoting change of state) in that they lack agentivity: the reflexive se thus removes this semantic trait from the lexical meaning of the base verbs. Due to unagentivity, the event expressed by decausatives appears to be uncontrolled, spontaneous or accidental, see esp. (Fehrmann et al. 2014) and for Czech Fried (2004): the semantic participant in the subject of decausatives can be tentatively identified with the participant in the direct object of their base verbs and it is interpreted as undergoing the change of state non-volitionally, as evidenced by incompatibility of decausatives with adverbials expressing intentionality (e.g., schválně 'on purpose') or with deliberately used instruments (e.g., lepidlem 'with glue'). ${ }^{17}$ The semantic change is reflected in the valency structure of decausatives as well: their valency structure is reduced by one valency position corresponding with their base verbs to direct object.

Decausative lexical reciprocals combine the above characteristics with the trait of mutuality, which is already present in the lexical meaning of their base verbs (e.g., kombinovat se 'to combine with sth' $\leftarrow$ kombinovat néco s něčím 'to combine sth with sth'; míchat se 'to mix with sth' $\leftarrow$ míchat něco s něćm 'to mix sth with sth'; misit se 'to mix with sth' $\leftarrow$ misit něco $s$ něćm 'to mix sth with sth'; sloučit se s něčím 'to merge with sth' $\leftarrow$ sloučit néco s něćm 'to merge sth with sth'; spojit se 'to combine with sth' $\leftarrow$ spojit néco s něčm 'to combine sth with sth'; srazitse 'to collide with sb/sth' $\leftarrow$ srazit néco s néčím 'to push sth/sb together by force'). With non-reflexive lexical reciprocals, forming base verbs of decausatives, mutuality involves the semantic participants in the direct object position and in the indirect object position. With decausative lexical reciprocals, the participants in the subject and indirect object position are affected. For syntactic properties of decausatives see Section 3.3.2.

15 I leave verb lemmas marked by the optional reflexive $s i$ aside here. In these cases, the use of the reflexive does not change the situational and structural meaning of a verb and does not lead to any changes in its surface syntactic features; only the pragmatic feature of pleasure is typically added (e.g., chodit (si) s někým 'to go out with sb').

16 Decausatives are also referred to as anticausatives (Medová 2009) and inchoatives (Reinhart, Siloni 2005).

17 If such an adverbial is present in a construction, the construction has a rather deagentive interpretation: see, e.g., the sentence Barvy se schválně smíchaly. 'Colors were deliberately mixed.' in which the adverbial schválně 'deliberately' implies an unexpressed human agent. For deagentive diathesis in Czech see (Panevová et al. 2014). 


\subsubsection{Autocausatives}

Some LRLs can be classified as autocausatives. Autocausatives border on true reflexives: while with true reflexives, the acting and affected entities are distinguished into two separate participants and the reflexive in a sentence just marks the fact that these participants have the same referent (e.g., Jana se lićila. 'Jane was putting on make-up.), with autocausatives the reflexive signals that the acting and affected entities are conflated into an indistinguishable single participant ${ }^{18}$. Autocausatives thus typically preserve the trait of agentivity in contrast to decausatives (Section 3.2.2.1), as evidenced by their semantic compatibility with adverbials expressing intentionality or deliberately used instruments ${ }^{19}$. The reconfiguration of semantic participants with autocausatives is projected in their valency structure, which is - in comparison with their base verbs - reduced by one valency position in the form of direct object (as in the case of decausatives, Section 3.2.2.1).

Autocausative lexical reciprocals combine the described properties with mutuality, which is already encompassed in the lexical meaning of their non-reflexive counterparts (e.g., křizit se 'to crossbreed with sth' in the sense 'These birds can crossbreed with other species' $\leftarrow$ křižit něco $s$ néčím 'to crossbreed sth with sth'; rozvést se 'to get divorced' $\leftarrow$ rozvést někoho s někým 'to divorce'; sbližit se 'to become close to sb' $\leftarrow$ sbližit někoho s někým 'to bring sb close to sb'; seznámit ses někým 'to make acquaintance with sb' « seznámit někoho s někým 'to introduce sb to sb'; smirìt se 'to make it up with sb' $\leftarrow$ smirit někoho s někým 'to reconcile sb with sb'; zasnoubit se 'to get engaged to $s \mathrm{~b}$ ' $\leftarrow$ zasnoubit někoho $s$ někým 'to engage sb to sb'; zneprátelit se 'to fall out with sb' $\leftarrow$ zneprátelit někoho $s$ někým 'to set sb against sb'). With non-reflexive lexical reciprocals, representing base verbs of autocausative lexical reciprocals, mutuality affects the semantic participants in the direct object and indirect object position. In contrast, with autocausative lexical reciprocals (similarly as with decausative lexical reciprocals, Section 3.2.2.1), the participants in the subject and indirect object position are affected. For syntactic properties of autocausative lexical reciprocals see Section 3.3.2.

18 See the concept of relative distinguishability of participants in (Kemmer 1993, p. 66), individuation of objects in (Haiman 1983, p. 795), and the so called self-affectedness of agent in (Fried 2004).

19 In some cases, the line between decausatives and autocausatives is, however, blurred and their interpretation depends on the context (e.g., the verb. oddělit se 'to separate' in Kŕrídlo se prri nárazu oddélilo od trupu letadla. 'The wing separated from the fuselage on impact.' has a decausative reading and in První dáma se oddělila od prezidenta. 'The First Lady separated from the President.' an autocausative meaning of this verb is rather at play). 


\subsubsection{Deaccusatives}

The last type of LRLs includes only a few verbs with which the reflexive serves as a pure intransitivizer: when deaccusative lexical reciprocals are compared with their non-reflexive counterparts, there are not any changes in their meaning, i.e., a set of semantic participants and their mapping onto valency complementations are preserved, see as well Geniušienè (1987, p. 94). The only change concerns the surface expression of the participant that is expressed with their base verbs as an accusative direct object; with deaccusatives, this participant is expressed as an indirect object (e.g., dohodnout se s někým na něčem ${ }_{\text {loc }}$ 'to agree with sb on sth' $\leftarrow$ dohodnout s někým něco acc 'to arrange sth with sb'; domlouvat ses někým na něčem ${ }_{\text {loc }}$ 'to agree with sb on sth' $\leftarrow$ domlouvat s někým něco acc 'to arrange sth with sb'). ${ }^{20}$

\subsubsection{Reflexive lexical reciprocals without non-reflexive counterparts}

Some reflexive lexical reciprocals have no non-reflexive counterparts (henceforth LRNs); these verbs are referred to as deponents as well (see, e.g., Kemmer 1993, p. 22; Knjazev 2007a, p. 118; Haspelmath 2007). Two types can be distinguished. First, a reflexive lexical reciprocal lacks a corresponding non-reflexive verb lemma (e.g., bratrit se 'to be friends with sb' $\leftarrow^{\star}{ }^{\star}$ bratriit; handrkovat se 'to haggle' $\leftarrow{ }^{\star}$ handrkovat; hašterit se 'to quarrel with sb' $\leftarrow{ }^{\star}$ hašterit; kamarádićkovat se 'to be friends with sb' $\leftarrow{ }^{*}$ kamarádićkovat; kočkovat se 'to horse around with $\mathrm{sb}$ ' ${ }^{\star}{ }^{*}$ kočkovat; loučit se 'to say goodbye to sb' $\leftarrow{ }^{*}$ loučit; miliskovat se 'to fondle with sb' $\leftarrow{ }^{*}$ miliskovat; pelešit se 'to fornicate with sb' $\leftarrow^{*}$ pelešit; podobat se 'to be similar' $\leftarrow{ }^{*}$ podobat; pohádat se 'to quarrel with sb' $\leftarrow{ }^{*}$ pohádat; poprat se 'to have a fight with sb' $\leftarrow{ }^{*}$ poprat; potýkat se 'to be faced with sb' $\leftarrow{ }^{*}$ potýkat; prátelit se 'to be friends with sb' $\leftarrow{ }^{*}$ prátelit; prít se 'to have a dispute with sb' $\leftarrow{ }^{\star}$ prrit; setkat se 'to meet up with sb' $\leftarrow{ }^{*}$ setkat; shodnout se 'to agree' $\leftarrow{ }^{*}$ shodnout; snoubit se 'to unite' $\leftarrow{ }^{\star}$ snoubit; spolčit se 'to band together' $\leftarrow{ }^{*}$ spolčit; spiknout se 'to conspire' $\leftarrow{ }^{*}$ spiknout; stýkat se 'to keep in touch with sb' $\leftarrow{ }^{*}$ stýkat).

Second, a corresponding non-reflexive verb lemma can be identified for a reflexive lexical reciprocal, however, none of its lexical units (senses) represents its derivational base (e.g., hádat se 'to quarrel with sb' but hádat něco 'to guess'; kurvit se 'to fornicate with sb' but kurvit 'to ruin sth'; prát se 'to fight with sb' but prát něco 'to do the washing'; rozejit se 'to break up with sb' but rozejit něco 'to get sth to work'; rvát se 'to fight with sb' but rvát néco 'to tear sth'; sejít se 'to meet up

20 With respect to the preserved meaning, the status of these verbs as separate verb lemmas representing lexical units is rather questionable. If this function of the reflexive was productive, it should be considered as morphological reflexive verb forms rather than separate verb lemmas. However, as their number in Czech is very limited, I rank them here in accordance with the tradition as separate verb lemmas (Filipec et al. 2007). 
with sb' but sejít něco 'to go down sth'; svářet se 'to be in dispute with sb' but svářet něco 'to weld sth'; utkat se 'to play against sb' but utkat něco 'to weave sth'; vadit se 'to quarrel with sb' but vadit někomu 'to bother'; zaplést se 'to have an affair with sb' but zaplést něco 'to weave sth into sth'). ${ }^{21}$

\subsection{Valency structure of reflexive lexical reciprocals}

\subsubsection{Reflexive lexical reciprocals derived from syntactic reciprocals}

In principle, LRSs (Section 3.2.1) exhibit uniform syntactic behavior (rare exceptions are addressed below). When the valency structure of these reflexive lexical reciprocals is compared with the valency structure of the syntactic reciprocals representing their non-reflexive counterparts, it can be observed that their valency structure is not reduced in the number of valency complementations: compare, e.g., the valency frame of the LRS navštevvovat se 'to visit each other' in (17) with the frame of the non-reflexive syntactic reciprocal navštévovat 'to visit', representing its base verb, in (19); see also the valency frame of the LRS dìvěrovat si 'to trust each other' in (21) and the frame of the syntactic reciprocal divvěrovat 'to trust', as its non-reflexive counterpart, in (23). ${ }^{22}$

With the non-reflexive syntactic reciprocals that represent base verbs of LRSs, the semantic participants that can be involved in mutuality are expressed by the nominative subject and either by the accusative direct object, see the frame in (19) and example (20), or by the dative indirect object, see the frame in (23) and example (24). With the LRSs, the subject position remains unchanged and the less prominent position is uniformly changed into the indirect object in the comitative form, see PAT in the frames in (17) and (21) and examples (18) and (22), respectively. LRSs in their base constructions can have either the singular (22) or plural agreement (18), in contrast to their reciprocal constructions resulting from the operation of syntactic reciprocalization where only the plural agreement is possible, see Section 2.2.

The change in the surface expression of the participant that is expressed in the less prominent position reflects the change in the meaning of LRSs (see Section 3.2.1): while with the syntactic reciprocals, the relation of mutuality between the semantic participants in the subject and direct or indirect object

${ }_{21}$ In case of the verbs sejit se 'to meet up with sb' and rozejit se 'to break up with sb', the derivation by the reflexive together with the prefix can be taken into account, see (Karlík et al. 1995).

22 The valency structure is described in terms of the valency theory of the Functional Generative Description (see esp. Panevová 1994). The abbreviations ACT, PAT etc. stand for the so-called functors, labeling the type of the dependency relation of a valency complementation to its governing verb, the numbers in the subscript of the functors indicate morphological cases, the abbreviation $d c c$ stands for dependent content clauses. The abbreviations $o b l$ and $o p t$ in the superscript describe obligatoriness of the complementation. 
position is only potential and for its expression the syntactic operation of reciprocalization must be applied (Section 2.2), with LRSs, the morphosyntactic change, affecting the participant in the less prominent position, manifests the mutual relation between the involved participants.

(17) navštěvovat se 'to visit each other': $\mathrm{ACT}_{1}$ obl $\mathrm{PAT}_{s+7}$ obl

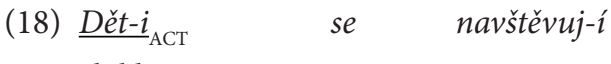
skamarád- $y_{\mathrm{PAT}}$ child-NOM.PL.N REFL visit-3.PL with friend-INSTR.PL.M

'Children and their friends visit each other.'

(19) navštévovat 'to visit': $\mathrm{ACT}_{1}^{\text {obl }} \mathrm{PAT}_{4}{ }^{\text {obl }}$

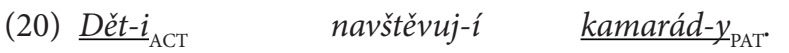
child-NOM.PL.N visit-3.PL friend-ACC.PL.M

'Children visit their friends.'

(21) di̊věřovat si 'to trust each other': $\mathrm{ACT}_{1}{ }_{1}{ }^{\text {ob }} \mathrm{PAT}_{\text {s+7 }}$ obl
(22) Lobs- $\emptyset_{\text {ACT }}$ si diověruj-e Jobs-NOM.SG.M REFL trust-3.SG
s Cook-em $_{\mathrm{PAT}}$ with Cook-INSTR.SG.M

'Jobs and Cook trust each other.'

(23) divvěrovat 'to trust': $\mathrm{ACT}_{1}{ }^{\text {obl }} \mathrm{PAT}_{3}^{\text {obl }}$

(24) $\underline{\operatorname{Lobs}-\emptyset}_{\mathrm{ACT}}$ důvěruj-e

Cook-ovi $i_{\text {PAT }}$ Jobs-NOM.SG.M trust-3.SG Cook-DAT.SG.M

'Jobs trusts Cook.'

If the valency structure of syntactic reciprocals representing non-reflexive base verbs of LRSs comprises other valency complementations in addition to those which can be affected by the syntactic reciprocalization, these complementations remain preserved in the valency structure of the derived LRSs, see, e.g., EFF in the valency frame of the verb oslovovat 'to call' in (25) and in the valency frame of the verb oslovovat se 'to call each other' in (27), and illustrating examples in (26) and (28), respectively.

(25) oslovovat 'to call': $\mathrm{ACT}_{1}{ }^{\text {obl }} \mathrm{PAT}_{4}{ }^{\text {obl }} \mathrm{EFF}_{5,7}{ }^{\text {obl }}$
(26) Učitel-é $e_{\text {ACT }}$
dět- $i_{\mathrm{PAT}}$
oslovuj-í
jemén- $y_{\mathrm{EFF}}$
teacher-NOM.PL.M
child-ACC.PL.N
call-3.PL
first name-INSTR.PL.N
'Teachers call children by their first names.'
(27) oslovovat se 'to call each other': $\mathrm{ACT}_{1}{ }_{1}^{\text {obl }} \mathrm{PAT}_{\text {s+7 }}$ ob $\mathrm{EFF}_{5,7}$ obl 
(28)

$\begin{array}{llll}\text { Učitel-é }_{\mathrm{ACT}} & s e & s \text { dět-mi } & \text { oslovuj-í } \\ \text { teacher-NOM.PL.M } & \text { REFL } & \text { with child-INSTR.PL.N } & \text { call-3.PL }\end{array}$

jimén-y ${ }_{\mathrm{EFF}}$

first name-INSTR.PL.N

'Teachers and children call each other by their first names.'

In rare cases, a LRS acquires an additional valency complementation. In such cases, the mutual relation between participants gives rise to other semantic shifts, compare, e.g., the valency frame of the syntactic reciprocal bit 'to beat' (29), illustrated by example (30), with the valency frame of the reflexive lexical reciprocal bit se 'to fight with sb' (31) derived from this syntactic reciprocal, exemplified by (32): the syntactic reciprocal bit 'to beat' expresses using physical violence against somebody (30) whereas the LRS derived from this verb bit se 'to fight with sb' refers to a mutual struggle that can be physical but also verbal or mental and for which the subject of dispute can be syntactically structured as PAT in the form $o+$ accusative, see example (32).

(29) bit 'to beat': $\mathrm{ACT}_{1}{ }^{\text {bbl }} \mathrm{PAT}_{4}{ }^{\text {obl }}$

(30) Když sedlák- $\emptyset_{\text {ACT }}$ when farmer-NOM.SG.M

bil-Ø kon- $\check{e}_{\mathrm{PAT}}, \cdots$

beat-3.SG.M horse-ACC.SG.M

'When a farmer beat his horse, ...'

(31) bit se 'to fight': $\mathrm{ACT}_{1}{ }^{\text {obl }} \mathrm{ADDR}_{\text {s+7 }}{ }^{\text {obl }} \mathrm{PAT}_{\mathrm{o}+4}{ }^{\text {opt }}$

(32) ekolog-ové ecologist-NOM.PL.M REFL beat-3.PL.M with technocrat-INSTR.PL.M

o jadernou energi- $i_{\mathrm{PAT}}$

about nuclear energy-ACC.SG.F

'Ecologists fought with technocrats about nuclear energy'.

\subsubsection{Reflexive lexical reciprocals derived from lexical reciprocals}

In contrast to LRSs (Section 3.3.1), the valency structure of decausative and autocausative lexical reciprocals, which are derived from non-reflexive lexical reciprocals (Section 3.2.2.1 and 3.2.2.2), is affected by valency reduction, see, e.g., the valency frame of the decausative lexical reciprocal sloučit se 'to merge with sth' in (33), illustrated by example (34), which is reduced by PAT in accusative as compared to the frame of its base lexical reciprocal verb sloučit 'merge sth with sth' $(35)^{23}$, exemplified in example (36). Similarly, when the valency frame of the autocausative usmirit se 'to make it up with sb' is compared with the valency frame of its base lexical reciprocal verb usmiriti 'to reconcile', it exhibits

23 For the so-called cognitive shifts of actants see esp. (Panevová et al. 2014). 
the reduction by the accusative PAT as well, compare the valency frames (37) and (39), illustrated by examples (38) and (40), respectively.

(33) sloučit se 'to merge': $\mathrm{ACT}_{1}{ }^{\text {obl }} \mathrm{ADDR}_{\mathrm{s}+7}{ }^{\text {obl }} \mathrm{PAT}_{\mathrm{do}+2, \mathrm{v}+}{ }^{\text {opt }}$

(34) Kdyby se sloučil-a somatická buňk-a ${ }_{A C T}$ if REFL combined-3.SG.F body cell-NOM.SG.F

$\underline{\mathrm{s} \text { vajičk-em }}{ }_{\mathrm{ADDR}}, \cdots$

with egg cell-INSTR.SG.N

'If a body cell combines with an egg cell, ...'

(35) sloučit 'to merge': $\mathrm{ACT}_{1}{ }^{\text {obl }} \mathrm{ADDR}_{\mathrm{s}+7}{ }^{\text {obl }} \mathrm{PAT}_{4}{ }^{\text {obl }} \mathrm{EFF}_{\mathrm{do}+2, \mathrm{v}+4}{ }^{\text {opt }}$

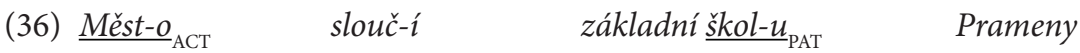

city-NOM.SG.N merge-3.SG primary school-ACC.SG.F Springs

s tamni mateřink-Ou ${ }_{\mathrm{ADDR}}$.

with local kindergarten-INSTR.SG.F

'The city will merge the primary school Springs with the local kindergarten.'

(37) Usmirit se 'to make it up': $\mathrm{ACT}_{1}{ }^{\text {obl }} \mathrm{PAT}_{\text {s+7 }}{ }^{\text {obl }}$

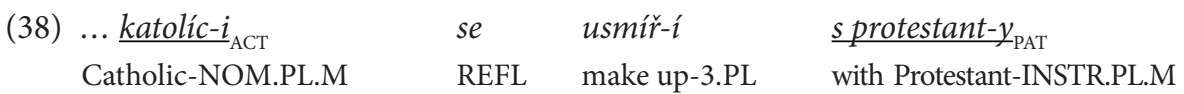

'Catholics will make peace with Protestants.'

(39) usmirít 'to reconcile': $\mathrm{ACT}_{1}{ }_{1}^{\text {obl }} \mathrm{ADDR}_{\text {s+7 }}{ }^{\text {obl }} \mathrm{PAT}_{4}{ }^{\text {obl }}$

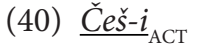

Czech-NOM.PL.M

usmir $-i \quad \underline{\text { Izraelc }}_{\mathrm{PAT}_{\mathrm{AT}}}$

$\underline{s \text { Palestinc- }}_{\text {ADDR }}$.

with Palestinian-INSTR.PL.M

'Czechs will reconcile Israelis with Palestinians.'

Further, with decausatives and autocausatives representing LRLs, the less prominent syntactic position affected by mutuality between semantic participants is not limited to the comitative form as it is with LRSs (see Section 3.3.1). For example, with the autocausative lexical reciprocal odtrhnout se 'to tear away', the less prominent position has the form od+genitive, see the valency frame in (41) and example (42). Similarly, with the decausative lexical reciprocal vázat se 'to bind to', it has the form $k+$ dative in addition to $s+$ instrumental (43) and (44).

(41) odtrhnout se 'to tear away': $\mathrm{ACT}_{1}^{\text {obl }} \mathrm{PAT}_{\text {od }+2}$ obl

(42) Lhot-a $a_{\text {ACT }}$ se odtrhl-a od Vsetín- $a_{\mathrm{PAT}}$ Lhota-NOM.SG.F REFL broke-3.SG.F away from Vsetín-GEN.SG.M

'Lhota broke away from Vsetín.' 
(43) vázat se 'to bind to': $\mathrm{ACT}_{1}{ }^{\text {obl }} \mathrm{PAT}_{\mathrm{k}+3, \mathrm{~s}+7}{ }^{\mathrm{obl}}$

(44) Podobné legend- $y_{\text {ACT }}$ se similar legend-NOM.PL.F REFL

váž-ou ke každému hrad-u PAT $_{\text {... }}$ bind-3.PL to every castle-DAT.SG.M

'Similar legends are connected with every castle.'

In contrast to decausative and autocausative lexical reciprocals, deaccusative lexical reciprocals (Section 3.2.2.3) are not characterized by the reduction of the valency position expressed with their non-reflexive base verbs by accusative; this position changes only the morphemic form from accusative into prepositional groups, compare PAT in the valency frames (45) and (47) and examples (46) and (48); this change leads to intransitivization of deaccusative lexical reciprocals.

(45) domlouvat se 'to agree with sb on sth': $\mathrm{ACT}_{1}^{\text {obl }} \mathrm{ADDR}_{\mathrm{s}+7}{ }^{\text {obl }} \mathrm{PAT}_{\mathrm{na}+6, \mathrm{o}+6, \mathrm{dcc}}{ }^{\text {obl }}$

(46) $U S A_{\mathrm{ACT}}$ USA domlouvaj-í arrange-3.PL

$\begin{array}{ll}\text { se } & \text { údajně } \\ \text { REFL } & \text { allegedly }\end{array}$

na útok- $u_{\text {PAT }}$ on attack-LOC.SG.M s Kurd- $y_{\mathrm{ADDR}}$ with Kurd-INSTR.PL.M

'It is said that the USA negotiate an attack with Kurds.'

(47) domlouvat 'to arrange sth with sb': $\mathrm{ACT}_{1}{ }^{\text {obl }} \mathrm{ADDR}_{\mathrm{s}+7}{ }^{\text {obl }} \mathrm{PAT}_{4, \mathrm{dcc}}{ }^{\text {obl }}$

(48) USA $A_{\mathrm{ACT}}$ údajně domlouvaj-í USA allegedly arrange-3.PL s Kurd- $y_{\mathrm{ADDR}}$ $\underline{u}$ tok- $\varnothing_{\mathrm{PAT}}$

'It is said that the USA negotiate an attack with Kurds.'

\section{Semantics of reflexive lexical reciprocals}

Below I introduce a list of lexical reciprocals derived from syntactic reciprocals, to which the reflexive contributes the semantic trait of mutuality (Section 3.2.1); these verbs have been found in the Czech National Corpus, SYNv8 (Křen et al. 2019), and partly in the VALLEX lexicon (Lopatková et al. 2016). ${ }^{24}$ In Section 4.1, I classify them into nine semantic groups, and then in Section 4.2, I identify their semantic overlaps with both reflexive lexical reciprocals derived from

24 The candidate verbs in SYNv8 have been selected on the basis of the following corpus query $[\operatorname{tag}=" \mathrm{~V}[\wedge \mathrm{s}]$."], searching verbs excluding their passive forms; then the positive filter [tag="R.*"\&lemma="s"], filtering the preposition $s$ 'with' in the context of three tokens from the found verbs on both sides, was applied. The verbs obtained on the basis of this query were filtered twice: first, with respect to the presence of the word form se and second, with respect to the occurrence of the form $s i$ in the left and right context of three words from the verbs. The resulting two lists of the verbs with the clitic reflexive se and si were ordered according to their frequency (the minimum was set to 10 occurrences in the data) and then manually analyzed.

In the VALLEX lexicon, the verbs were found on the basis of the value derived-recipr of the attribute reflexverb, identifying LRSs. 
non-reflexive lexical reciprocals (Section 3.2.2) and reflexive lexical reciprocals without non-reflexive counterparts (Section 3.2.3).

\subsection{Semantic groups}

\subsubsection{Antagonistic actions}

Many LRSs denote antagonistic actions; these actions can be carried out physically (bit se 'to fight with sb'; fackovat se 'to slap each other's face'; mačkat se 'to crowd together'; mlátit se 'to beat each other'; pobit se 'to have a fight with sb'; pohlavkovat se 'to cuff each other'; popadnout se 'to fight with sb'; poštuchovat se 'to push each other'; ř ezat se 'to thrash each other'; strkat se 'to push and shove each other'; škrtit se 'to strangle each other'; tlouci se 'to beat each other'; trkat se 'to butt each other'; trískat se 'to thrash each other'), mentally (nenávidèt se 'to hate each other'; vadit si 'to bother each other'), or as a speech act (hecovat se 'to goad each other'; nadávat si 'to curse each other'; popichovat se 'to taunt each other'; poškorpit se 'to have a quarrel with sb'; škádlit se 'to tease each other'; špickkovat se 'to tease each other'). In some cases, the manner of the antagonistic action remains underspecified (napadat se 'to attack each other'; prekážet si 'to disturb each other'; ublizit si 'to cause harm to each other').

\subsubsection{Rivalry}

This subgroup of LRSs is formed by verbs indicating rivalry, performed as a physical action (předjiždět se 'to pass each other'; přetlačovat se 'to push against each other'), as a mental action (konkurovat si 'to compete with sb'), or as a speech act (překrikovat se 'to be shouting each other down'); with some verbs, more than one manner in which an action is conducted is available (predhánět se 'to compete with sb'; trumfovat se 'to trump each other').

\subsubsection{Team games}

This group contains LRSs that denote mutual actions implied by games played in pairs or in bigger teams (házet si 'to throw a ball to each other'; honit se 'to chase each other'; kopat si 'to play football with sb'; koulovat se 'to snowball each other'; nahrávat si 'to pass a ball to each other'; pinkat si 'to hit the ball with sb'; prihrát si 'to pass sth to each other'); it is mutual cooperation between players that is foregrounded in this group rather than measuring players' performance against each other as with the verbs from the rivalry group (Section 4.1.2).

\subsubsection{Affectionate actions}

This semantic group comprises LRSs that refer to manifestations of affection; they can be mental (divvěrovat si 'to trust each other'; snášet se 'to get on with sb'; verrit si 'to trust each other'; vyhovovat si 'to satisfy each other') or physical (držet 
se s někým za ruku 'to hold each other's hands'; hladit se 'to caress each other'; laskat se 'to fondle each other'; líbat se 'to kiss'; milovat se 'to make love with each other'; mazlit se 'to caress each other'; muchlovat se 'to make out with sb'; objimat se 'to hug each other'; olizovat se 'to kiss'; polibit se 'to kiss'; pomilovat se 'to make love to each other'; pusinkovat se 'to kiss'; vést se 'to walk hand in hand'). LRSs denoting assistance can be included here as well (podporovat se 'to support each other'; pomáhat si 'to help each other'; vypomáhat si 'to assist each other').

\subsubsection{Encountering and greeting}

LRSs can express encountering (potkat se 'to meet with sb'; shledat se 'to meet each other again'; stretnout se 'to meet with sb'; vidèt se 'to see each other again'; uvidèt se 'to see each other'), including its negative variant (minout se 'to pass each other'). This group further contains the verbs that denote making relationships (kontaktovat se 'to get in touch with sb'; najit se 'to find each other'; otukávat se 'to check out each other'; poznat se 'to get to know each other'; zkontaktovat $s e$ 'to get in touch with each other'), having relationships (znát se 'to know each other') and maintaining them (navštervovat se 'to visit each other'; svolat se 'to call each other'). A group of verbs expressing greeting, conducted as speech acts and/ or gestures, stands close to these verbs (mávat si 'to wave at each other'; oslovovat se 'to call each other'; podat si ruku, potrást si rukou 'to shake hands with each other'; pozdravit se, privitat se 'to greet each other'; trást si rukou 'to shake hands with each other'; uvitat se 'to say hello to each other'; vitat se 'to greet with each other'; zamávat si 'to wave at each other'; zdravit se 'to greet each other').

\subsubsection{Exchanging}

Verbs expressing exchange form another group of LRSs. With the reflexive se, the exchangers are at the same time the exchanged entities (měnit se, prostřidat se, střídat se, vyménit se, vystřídat se 'to take turns' in the sense Petr se ménil/ prostřídal/strídal/vyménil/vystřídal s Janem $v$ hlídání. 'Peter and John took turns babysitting.') ${ }^{25}$. While with the reflexive $s i$, the exchangers and the exchanged objects are different entities ( $p$ ředat si 'to hand over sth to each other'; prehazovat $s i$ 'to change sth with each other'; prijčovat si 'to lend sth to each other'; rozdělovat $s i$ 'to share sth with each other').

\subsubsection{Physical convergence}

Another group is represented by LRSs referring to the spatial relation of convergence. The semantic participants in the mutual relation with these verbs are typically physical entities (kř́žitse 'to intersect' in the sense Cesta se křiží s hlavní

25 In VALLEX, the verb měnit se included in this group is considered as derived from the lexical unit of the non-reflexive verb měnit exemplified, e.g., by Lékař mění ve službě svého mladšího kolegu 'The doctor takes turn on night shifts with his younger colleague'. 
silnici' 'The road intersects the main road'; proplést se 'to interweave with each other'; prostoupit se 'to spread through each other'; protnout se 'to cross each other'; prekrýt se 'to overlap').

\subsubsection{Agreement and disagreement}

LRSs can also express agreement (doplňovat se 'to complement each other'; porozumert si 'to understand each other'; prizvukovat si 'to agree with each other'; rozumét si 'to get along with each other'; sednout si 'to be in accordance') and disagreement (odporovat si 'to contradict'). A specific subgroup overlapping to some extent with this semantic field is formed by the verbs denoting similarity and dissimilarity (dublovat se 'to duplicate each other').

\subsubsection{Interlocution}

A large group of LRSs is represented by verbs expressing a mutual relation between communicators. In the corpus data, only verbs derived by the reflexive $s i$ have been found. This fact can be accounted for on the basis of the syntactic structure of their base syntactic reciprocals: the semantic participant that can be involved in the mutual relation with these base verbs and that is expressed in a less significant surface position has the form of dative (typically encoding Recipient with communication verbs) (esemeskovat si 'to text each other'; gratulovat si 'to congratulate each other'; mailovat si 'to email each other'; poprát si 'to congratulate each other'; posílat si sms, zprávy, dopisy etc. 'to send sms, emails, letters etc. to each other'; povídat si 'to talk with each other'; povykládat si, povyprávét si 'to have a chat with sb'; prát si 'to congratulate each other'; $p s a ́ t ~ s i$ 'to write sth to each other'; ríkat si 'to talk with sb'; sdělovat si 'to communicate sth to each other'; skypovat si 'to skype with sb'; slibit si 'to promise sth to each other'; sverrovat si 'to confide sth to each other'; šeptat si, špitat si, šuškat si 'to whisper sth to each other'; tykat si 'to be on first-name terms with each other'; ujasnit si, upresnit si 'to make sth clear to each other'; volat si 'to call each other'; vyjasnit $s i$ 'to straighten sth out with sb'; vykat si 'to be on formal terms with each other'; vykládat si, vyprávět si 'to tell each other sth'; vysvétlit si 'to explain sth to each other'; zatelefonovat si, zavolat si 'to phone each other').

\subsubsection{Concluding remarks on semantic groups}

LRSs exhibit very similar properties with respect to semantic types of their participants. Semantic participants in the mutual relation with LRSs are mostly sentient - predominantly human - beings (Sections 4.1.1-4.1.5 and 4.1.9); the only exceptions are represented by the LRSs that denote physical convergence (Section 4.1.7), partly dis/agreement (e.g., odporovat si 'to contradict', Section 4.1.8) and exchanging (e.g., strídat se 'to take turns', Section 4.1.6) with which participants of other types are available. In contrast, a configuration of events denoted 
by these verbs is not uniform with respect to whether they involve sub-events or not and whether sub-events, if distinguishable, happen simultaneously or sequentially $^{26}$. The Czech data show that many LRSs express events that cannot be segmented into sub-events and that they can be rather interpreted as a single event (e.g., nenávidèt se 'to hate each other' from the group of antagonistic actions, Section 4.1.1; konkurovat si 'to compete with sb' from the group of rivalry, Section 4.1.2; and líbat se 'to kiss' from the group of affectionate actions, Section 4.1.4). However, some LRSs denote events involving different sub-events which can be interpreted as a series of asymmetrical actions mostly with the sequential reading (e.g., házet si 'to throw each other a ball' from the group of team games, Section 4.1.3; navštévovat se 'to visit each other' from the group of encountering, Section 4.1.5; piojčovat si 'to lend sth to each other' from the group of exchange, Section 4.1.6; mailovat si 'to email each other' and sverrovat si 'to confide sth to each other', Section 4.1.9). Further, for some LRSs, both sequential and simultaneous readings of their sub-events are available (e.g., tlouci se 'to beat each other' from Section 4.1.1 and zamávat si 'to wave at each other' from Section 4.1.5).

\subsection{Semantic overlaps of reflexive lexical reciprocals}

The semantic groups of LRSs, as introduced in Sections 4.1.1-4.1.9, semantically overlap with both LRLs (Section 3.2.2) and LRNs (Section 3.2.3).

Within LRLs, decausatives (Section 3.2.2.1) overlap to a great extent with the LRSs from the semantic group of physical convergence (compare the decausatives kombinovat se 'to combine with sth'; míchat se 'to mix with sth'; mísit se 'to mix with sth'; sloučit se 'to merge with sth'; spojit se 'to combine with sth' with the verbs introduced in Section 4.1.7). Autocausatives (Section 3.2.2.2) overlap with those semantic groups of LRSs that imply a human agent, namely with the semantic groups of encountering (compare the autocausatives seznámit se to make acquaintance with sb' and sblizit se 'to become close to sb' with the verbs in Section 4.1.5). In addition, they are close to the groups of affectionate actions (compare the autocausatives smirit se 'to make it up with sb' and zasnoubit se 'to get engaged to sb' with the verbs in Section 4.1.4) and antagonistic actions (compare the autocausatives rozvést se 'to get divorced' and zneprátelit se 'to fall out with sb' with the verbs in Section 4.1.1). However, while the LRSs primarily denote physical or mental manifestations of antagonism or affection (Sections 4.1.1 and 4.1.4), the autocausatives mostly express the arrangement of social relations. Deaccusatives (Section

26 Some scholars assume that lexical reciprocals primarily imply events which cannot be differentiated into sub-events, see the so-called irreducible symmetry by Dimitriadis (2004; 2008). See further Kemmer (1993) and Siloni (2008) as well. 
3.2.2.3) align with the group of interlocution verbs (compare dohodnout se and domlouvat se 'to agree with sb on sth' with the verbs in Section 4.1.9).

LRNs (Section 3.2.3) exhibit similar semantic overlaps with LRSs as autocausatives (Section 3.2.2.2). They overlap mainly with the semantic groups of antagonistic actions (compare hádat se 'to quarrel with sb'; handrkovat se 'to haggle'; hašterit se, pohádat se 'to quarrel with sb'; poprat se 'to have a fight with sb'; potýkat se 'to be faced with sb'; prát se 'to fight with sb'; prít se 'to have a dispute with sb'; rozejit se 'to break up with sb'; rvát se 'to fight with sb'; sváret se 'to be in dispute with sb'; utkat $s e$ 'to play against sb'; vadit se 'to quarrel with sb' with the verbs provided in Section 4.1.1). Further, they overlap with the group of affectionate actions (compare bratrit $s e$ 'to be friends with sb'; kamarádićkovat se 'to be friends with sb'; kočkovat se 'to horse around with'; miliskovat se 'to fondle with sb'; pelešit se 'to fornicate with sb'; prátelit se 'to be friends with sb'; spolčit se 'to band together'; spiknout se 'to conspire'; zaplést se 'to have an affair with sb' in Section 4.1.4), with the group of encountering and greeting (compare loucit se 'to say goodbye to sb'; sejit se, setkat se 'to meet up with sb'; stýkat se 'to keep in touch with sb' with the verbs from Section 4.1.5) and with the group of agreement (compare podobat se 'to be similar' and shodnout se 'to agree' with the verbs in Section 4.1.8).

\section{Conclusion}

I have shown here that lexical reciprocals the verb lemmas of which are marked by the reflexive can be distinguished into separate groups on the basis of the role of the reflexive played in their derivation and that these separate groups of verbs differ to some extent in syntactic constructions they form. However, all these reflexive lexical reciprocals semantically converge into a few semantic groups the common denominator of most of which is the social interaction between primarily human beings. The use of the reflexive as a derivational means mostly brings about systemic changes in the configurations of semantic participants: (i) with LRSs (reflexive lexical reciprocals derived from non-reflexive syntactic reciprocals), it results in the equal involvement of semantic participants in the denoted events, and (ii) with LRLs (reflexive lexical reciprocals derived from nonreflexive lexical reciprocals) of decausative and autocausative type, it leads to the reduction of participants. In both cases, these semantic changes result in systemic morphosyntactic changes with these verbs. The only exception is represented by LRLs of the deaccusative type with which only morphosyntactic changes occur without any apparent rearrangement of participants. An account of syntactic and semantic functions of the reflexive that forms part of verb lemmas of LRNs (reflexive lexical reciprocals without non-reflexive counterparts) requires a thorough diachronic exploration, which, however, goes beyond 
the scope of this paper. The analysis provided here, nevertheless, points out to a striking semantic similarity of these verbs with those reflexive lexical reciprocals for which non-reflexive counterparts can be identified.

\section{Bibliography}

Dalrymple, M. et al. (1998). Reciprocal Expressions and the Concept of Reciprocity, Linguistics and Philosophy, 21(2), 159-210.

Dimitriadis, A. (2004). Discontinuous Reciprocals (unpublished manuscript). Utrecht Institute of Linguistics OTS, Utrecht.

Dimitriadis, A. (2008). Irreducible symmetry in reciprocal constructions. In: E. König, V. Gast (eds.), Reciprocals and Reflexives (375-409). Berlin-New York: Mouton de Gruyter.

Evans, N. (2007). Complex events, propositional overlay, and the special status of reciprocal clauses. In: J. Newman, S. Rice (eds.), Proceedings of $7^{\text {th }}$ Conference on Conceptual Structure, Discourse and Language (CDSL). Stanford: CSLI.

Evans, N. (2008). Reciprocal constructions: Towards a structural typology. In: E. König, V. Gast (eds.), Reciprocals and Reflexives (33-103). Berlin-New York: Mouton de Gruyter.

Evans, N. et al. (2011). Introduction: Reciprocals and semantic typology. In: N. Evans et al. (eds.), Reciprocals and Semantic Typology (1-28). Amsterdam-Philadelphia: John Benjamins.

Frajzyngier, Z. (2000). Coding of the Reciprocal Function: Two Solutions. In: Z. Frajzyngier, T. S. Curl (eds.), Reciprocals. Forms and Functions (179-194). Amsterdam-Philadelphia: John Benjamins.

Fehrmann, D. et al. (2014). Slavic Reflexive Decausative, Russian Linguistics, 38(3), 287-313.

Filipec, J. et al. (eds.). (2007). Slovník spisovné češtiny pro školu a veřejnost. Praha: Academia.

Fried, M. (2004). Reflexivization and the Invariance Principle Revisited, The Slavic and East European Journal, 48(4), 627-653.

Geniušienè, E. (1987). The Typology of Reflexives. Berlin-New York-Amsterdam: Mouton de Gruyter.

Haiman, J. (1983). Iconic and Economic Motivation, Language, 59(4), 781-819.

Haspelmath, M. (2007). Further remarks on reciprocal constructions. In: V. P. Nedjalkov (ed.), Reciprocal Constructions (2087-2115). Amsterdam-Philadelphia: John Benjamins.

Ivanová, M. (2020). Reciprocita v slovenčině a optimalizácia jej lexikografického spracovania, Slovenská reč, 85(2), 143-161.

Karlík, P. (1999). Reflexiva v češtině. In: E. Rusínová (ed.), Přednášky a besedy z 32. běhu Letní školy slovanských studií (44-52). Brno: Filozofická fakulta Masarykovy univerzity.

Karlík, P. et al. (1995). Př́ruční mluvnice češtiny. Praha: Nakladatelství Lidové noviny. 
Kemmer, S. (1993). The Middle Voice. Amsterdam-Philadelphia: John Benjamins.

Kettnerová, V. (2014). Lexikálně-sémantickékonverze ve valenčním slovníku. Praha: Karolinum.

Kettnerová, V., Lopatková, M. (2018). Lexicographic Potential of the Syntactic Properties of Verbs: The Case of Reciprocity in Czech. In: J. Čibej et al. (eds.), XVIII EURALEX International Congress, Lexicography in Global Contexts (685-698). Ljubljana: Ljubljana University Press.

Kettnerová, V., Lopatková M. (2019). Reflexives in Czech from a Dependency Perspective. In: K. Gerdes, S. Kahane (eds.), Proceedings of the Fifth International Conference on Dependency Linguistics (Depling, Syntaxfest 2019) (14-25). Paris: Association for Computational Linguistics.

Kettnerová, V., Lopatková, M. (2020). Ke způsobům vyjádření vzájemnosti v češtině, Slovo a slovesnost, 81(4), 243-268.

Knjazev, J.P. (2007a). Lexical reciprocals as a means of expressing reciprocal situations. In: V.P. Nedjalkov (ed.), Reciprocal Constructions (115-146). Amsterdam-Philadelphia: John Benjamins.

Knjazev, J.P. (2007b). Reciprocal constructions in Russian. In: V.P. Nedjalkov (ed.), Reciprocal Constructions (673-707). Amsterdam-Philadelphia: John Benjamins.

König, E., Gast, V. (2008). Reciprocity and reflexivity - description, typology and theory. In: E. König, V. Gast (eds.), Reciprocals and Reflexives. Theoretical and Typological Explorations (1-31). Berlin-New York: Mouton de Gruyter.

König, E., Kokutani, S. (2006). Towards a typology of reciprocal constructions: focus on German and Japanese, Linguistics, 44(2), 271-302.

Kováčová, K. (2005). Konverzívnost jako systémový vztah (doctoral thesis). Filozofická fakulta, Univerzita Karlova, Praha.

Křen, M. et al. (2019). Korpus SYN, verze $8 z$ 12. 12. 2019. Ústav Českého národního korpusu FF UK, Praha 2019. https://www.korpus.cz.

Langendoen, D.T. (1978). The Logic of Reciprocity, Linguistic Inquiry, 9(2), 177-197.

Lopatková, M. et al. (2016). Valenční slovník českých sloves VALLEX. Praha: Karolinum.

Maslova, E. (2008). Reflexive encoding of reciprocity: Cross-linguistic and language-internal variation. In: E. König, V. Gast (eds.), Reciprocals and Reflexives (225-257). Berlin-New York: Mouton de Gruyter.

Maslova, E., Nedjalkov, V.P. (2013). Reciprocal Constructions. In: S.M. Dryer, M. Haspelmath (eds.), The World Atlas of Language Structures Online. Leipzig: Max Planck Institute for Evolutionary Anthropology. http://wals.info/chapter/106.

Medová, L. (2009). Reflexive Clitics in the Slavic and Romance Languages. A Comparative View from an Antipassive Perspective (doctoral thesis). Department of Slavic Languages and Literatures, Princeton University, Princeton.

Nedjalkov, V.P. (2007). Overview of the research. Definitions of terms, framework, and related issues. In: V.P. Nedjalkov (ed.), Reciprocal Constructions (3-114). Amsterdam-Philadelphia: John Benjamins. 
Oliva, K. (2001). Reflexe reflexivity reflexiv, Slovo a slovesnost, 62(3), 200-207.

Panevová, J. (1994). Valency Frames and the Meaning of the Sentence. In: P.L. Luelsdorff (ed.), The Prague Linguistic School of Structural and Functional Linguistics (223-243). Amsterdam-Philadelphia: John Benjamins.

Panevová, J. (1999). Česká reciproční zájmena a slovesná valence, Slovo a slovesnost, 60(4), 269-275.

Panevová, J. (2007). Znovu o reciprocitě, Slovo a slovesnost, 68(2), 91-100.

Panevová, J., Mikulová, M. (2007). On reciprocity, The Prague Bulletin of Mathematical Linguistics, 87, 27-39.

Panevová, J. et al. (2014). Mluvnice současné češtiny. Syntax češtiny na základě anotovaného korpusu. Praha: Karolinum.

Penchev, J. (2007). Reciprocal and reflexive constructions in Bulgarian. In: V.P. Nedjalkov (ed.), Reciprocal Constructions (609-632). Amsterdam-Philadelphia: John Benjamins.

Plank, F. (2008). Thoughts on the origin, progress, and pronominal status of reciprocal forms in Germanic, occasioned by those of Bavarian. In: E. König, V. Gast (eds.), Reciprocals and Reflexives (346-373). Berlin-New York: Mouton de Gruyter.

Reinhart, T., Siloni, T. (2005). The Lexicon-Syntax Parameter: Reflexivization and Other Arity Operations, Linguistic Inquiry, 36(3), 389-436.

Siloni, T. (2008). The Syntax of Reciprocal Verbs: An Overview. In: E. König, V. Gast (eds.), Reciprocals and Reflexives (451-498). Berlin-New York: Mouton de Gruyter.

Svoboda, O. (2014). Functions of the Czech reflexive marker se/si (master thesis). Faculty of Humanities, Leiden University, Leiden.

Štícha, F. et al. (2013). Akademická gramatika spisovné češtiny. Praha: Academia.

Veselý, V. (2018). K slovotvorné funkci reflexivních morfémů se, si, Naše řeč, 101(3), $138-157$.

Wiemer, B. (2007). Reciprocal and reflexive constructions in Polish. In: V.P. Nedjalkov (ed.), Reciprocal Constructions (513-559). Amsterdam-Philadelphia: John Benjamins.

\section{ZWROTNE DERYWATY CZASOWNIKOWE O ZNACZENIU RECYPROKALNYM W JĘZYKU CZESKIM}

ABSTRAKT: W języku czeskim (podobnie jak w innych językach słowiańskich) klityki
refleksywne służą - między innymi - jako środek derywacji czasowników recyprokal-
nych, czyli takich, które zawierają wzajemnośc bezpośrednio w znaczeniu leksykalnym.
W artykule odróżniam te czasowniki, u których wzajemność wyrażona jest przez klitykę
zwrotną (nenávidèt se 'nienawidzić siebie wzajemnie' $\leftarrow$ nenávidět 'nienawidzić kogoś'
i slíbit si 'obiecać sobie coś wzajemnie’ $\leftarrow$ slíbit 'obiecać coś komuś), od tych czasowników 
wzajemnych, przy których pełnią te klityki inną funkcję (oddělit se 'oddzielić się od siebie' $\leftarrow$ oddělit 'oddzielić kogoś/coś od kogoś/czegoś). Czasownik recyprokalne pierwszego typu tworzą konstrukcje, w których uczestników w stosunku wzajemności wyrażano typowo w pozycji subjektu i objektu dalszego w narzędniku (Petr si slíbil s Marií věrnost. 'Piotr i Maria obiecali sobie nawzajem wierność'). Czasowniki te dzielą się na kilka klas semantycznych, które jednak semantycznie w dużym stopniu są takie same jak klasy czasowników recyprokalnych innych typów. 